\title{
The Destructive Impact of Burned Peatlands to Physical and Chemical Properties of Soil
}

\author{
Deasy ARISANTY ${ }^{I}$, Karol JEZDRASIAK ${ }^{2}$, Ismi RAJIANI * and Janusz GRABARA ${ }^{4}$
}

\author{
Authors' affiliations and addresses: \\ ${ }^{1}$ Lambung Mangkurat University, Jl. Brigjend $\mathrm{H}$. \\ Hasan Basry, Banjarmasin 70123, Indonesia \\ e-mail: deasyarisanty@ulm.ac.id \\ ${ }^{2}$ Faculty of Applied Sciences, Department of \\ Transport and IT, WSB University, Zygmunta \\ Cieplaka 1c, 41-300 Dąbrowa Górnicza, Poland \\ e-mail: jedrasiak.karol@gmail.com \\ ${ }^{3}$ Lambung Mangkurat University, Jl. Brigjend H. \\ Hasan Basry, Banjarmasin 70123, Indonesia \\ e-mail: rajiani@ulm.ac.id \\ ${ }^{4}$ The Management Faculty, Czestochowa \\ University of Technology, Armii Krajowej 19B, \\ 42-201 Częstochowa, Poland and Al-Farabi \\ Kazakh National University, Kazakhstan \\ e-mail: janusz@grabara.eu \\ *Correspondence: \\ Ismi Rajiani, Lambung Mangkurat University, Jl. \\ Brigjend H. Hasan Basry, Banjarmasin 70123 , \\ Indonesia \\ tel.: +62812342322298 \\ e-mail: rajiani@ulm.ac.id \\ How to cite this article: \\ Arisanty, D., Jędrasiak, K., Rajiani, I. and Grabara, J. \\ (2020). The Destructive Impact of Burned Peatlands \\ to Physical and Chemical Properties of Soil. Acta \\ Montanistica Slovaca, Volume 25 (2), 213-223 \\ DOI: \\ https://doi.org/10.46544/AMS.v25i2.8
}

\begin{abstract}
Peatland fires occur every year in the South Kalimantan Province Indonesia, particularly affecting soil characteristics. The purposes of this study are to analyse the physical aspects of soil (colour and soil texture) caused by fires and to investigate the chemical characteristics of soil $\left(\mathrm{pH}, \mathrm{Fe}^{2+}, \mathrm{P}_{2} \mathrm{O}_{5}\right.$, and $\left.\mathrm{K}_{2} \mathrm{O}\right)$. This study used measurements in the field based on a map of peatland fires in the region and laboratory results. There were 24 samples in this study; they were taken in October 2018, which was about a month after the fire, and in January 2019, which was about four months after the burning. The samples were analysed regarding the soil colour, texture, $\mathrm{pH}, \mathrm{Fe}^{2+}, \mathrm{P}_{2} \mathrm{O}_{5}$, and $\mathrm{K}_{2} \mathrm{O}$. The results of the study indicated that the characteristics of the soil on burned land in October 2018 had higher $\mathrm{pH}, \mathrm{P}_{2} \mathrm{O}_{5}$, and $\mathrm{K}_{2} \mathrm{O}$ levels than in January 2019. Fires occurred in soil brought changes to the soil physical and chemical properties. The added combustion ash affected the physical and chemical properties of the land, such as soil colour, texture, $\mathrm{pH}$, $\mathrm{P}_{2} \mathrm{O}_{5}, \mathrm{~K}_{2} \mathrm{O}$, and $\mathrm{Fe}^{2+}$.
\end{abstract}

\section{Keywords}

Peatland, land burning, soil characteristics 


\section{Introduction}

Land fires in Indonesia are regional and global disasters. They do not only bring impacts to Indonesia, but gas emission from the combustion also affect neighbouring countries (Nugroho, 2017). Fires in Indonesia occur not only on dry land but also on wetlands (Cahyono et al., 2015; Rauf, 2016). In wetlands, they often burn on deep organic soils that accumulate in this ecosystem. Fires can occur on high-frequency wetlands that will increase in the future (Brown et al., 2015; Watts \& Kobziar, 2013), one of which is on peatland.

Peatlands in Indonesia are estimated at 20.6 million hectares or around $10.8 \%$ of Indonesia's land area. Peatland fire in Indonesia regularly occurs in the dry season. The dry season is compounded by the number of dry days within the dry season or the El Niño, and the drainage system of peatland (Novitasari et al., 2019; Nugroho, 2017). In the reaction of peatland burning, the Indonesian government has propelled an activity to reestablish more than 2 million ha of peatland between presently and 2020 for Kalimantan, Sumatra, and Papua Islands (Hansson \& Dargusch, 2017).

Kalimantan peatland area reaches 5.7 ha, or $27.8 \%$ of the island (Wahyunto \& Suparto, 2004) and this area becomes the main location of Reducing Emissions from Deforestation and forest Degradation (REDD + ) which is a project of sustainable management of forests and enhancement of forest carbon stocks in developing countries (Rajiani \& Pypłacz, 2018). Peatland in South Kalimantan is always burned every year (Arisanty et al., 2019; Vetrita \& Cochrane, 2020). The area burned in South Kalimantan Province has increased in the last 3 years. The burned area reached 2,331.96 Ha in 2016; 8,290.34 Ha in 2017 and raised to 98,637.99 Ha in 2018. Most of the peatlands in South Kalimantan Indonesia are at risk of experiencing fires. In January $1^{\text {st }}$ to September $14^{\text {th }}, 2018,552$ land fires were causing the area to burn up to thousands of hectares. The most burned land area occurred in Banjarbaru, which reached 467.03 hectares and mostly located on peatland (Kumparan, 2018).

Peatlands in South Kalimantan are classified as thin and medium peat soils (Wahyunto \& Suparto, 2004). Fires every year occurred on peatlands increasingly cause degraded soil conditions in South Kalimantan. Research on the impact of peat fires on the physical and chemical characteristics of soils in Indonesia is still limited, especially in South Kalimantan, although fires continue to occur every year in the South Kalimantan region.

\section{Burned Peatland}

\section{Literature Review}

Peatlands are lands rich in organic material with organic $\mathrm{C}>18 \%$ and a minimum thickness of $50 \mathrm{~cm}$. Natural materials on peat soil are formed from undecayed plant remnants and are often found in swampy areas or poorly drained basins. Peat soils are generally formed in water-saturated and nutrient-poor conditions (Agus et al., 2019; Xu et al., 2018). They consist of at least $30 \%$ of dead organic matter's dry mass. Peatlands can have vegetation and no peat on its surface (Joosten, 2009). In general, the minimum thickness of peat in a bog is 30 cm (Joosten et al., 2012).

Peatlands play critical economic and ecological roles (Saputra, 2019) and are crucial for the life of human culture (Xu et al., 2018). Human interference in peatland management causes damage. Problems occurring in peatlands are fire, deforestation, land subsidence (Saputra, 2019), and agricultural land clearing (Frolking et al., 2011). The inventory of peatland potential is still shallow due to the problematic interpretation of satellite imagery and the low data obtained through field measurements (Joosten, 2009). It is crucial to conserve peatland ecosystems since they have essential functions, which are the preservation of water resources, flood suppression, prevention of seawater intrusion, supporting various life/biodiversity, and climate control as it is one of the carbon supplies (Wahyunto \& Suparto, 2004; Wiri et al., 2017).

Human is the highest factor in causing the damage (Prayoto et al., 2017; Tacconi, 2003); for instance, community's lack of the attention to peatlands, forest conversion on a peatland such as land clearing and plantations with inappropriate trenching and peatland fires (Prayoto et al., 2017). However, drying as a result of climate alter and human action brings down the water table in peatlands and increments the recurrence and degree of peat fires (Turetsky et al., 2015).

Cultivated peatlands are more vulnerable to fires than conserved ones (Prayoto et al., 2017). The vulnerability is best characterised as a total degree of human welfare that integrates a natural, social, financial and political introduction to a run of potential hurtful annoyances (Blistanova et al., 2016). Burning peatlands is considered the easiest way to clear them; the community also deems it can increase soil fertility (Wiri et al., 2017; Zulkifli \& Kamarubayana, 2017). Fires on peatlands are more difficult to extinguish than the others. Areas with extensive and deep peatland will take years to ensure that the fires have been completely extinguished (Jones, 2005). The dynamics of peat fires are caused by the exploitation of large-scale agricultural and plantation activities. These activities are followed by forest clearing and peatland drainage so that it made the peatland dry; if accompanied by a long dry season, everything can increase the danger level of fires (Page, 2016). Conversion of secondary forests by cutting down and burning organic matter that converted into available nutrients will 
increase the $\mathrm{pH}$ of the soil at the surface of the soil. However, these nutrients are easily dissolved by high rainfall. Land becomes degraded over a long period of time and flammable during the dry season (Agus et al., 2020). To make it worst, burned peat forests need 27 to 47 years to recover, depending on the environment in which the vegetation grows (Marlier et al., 2019).

\section{Effect of fire for soil characteristics}

Combustion of peatlands can cause damage to peat soil. The soil physical nature determines the land quality because land with excellent physical properties will provide good environmental quality (Susandi et al., 2015). The peat characteristics affected by open-fire have undergone extreme changes (Könönen et al., 2015). Peat soil burned has decreased water content, water binding power, porosity, and permeability while Bulk Density (BD) and Particle Density (PD) has increased, compared to non-burning peat soil. Fire decreases total carbon (TC), total nitrogen $(\mathrm{TN})$, and organic phosphorus $\left(\mathrm{P}_{\mathrm{o}}\right)$, but fire increases inorganic phosphorus $\left(\mathrm{P}_{\mathrm{i}}\right)$ and total calcium (TCa) (Smith et al., 2001). The microbial abundance and phosphatase movement within the burned soils substantially diminished compared to those of the unburned soil (Sazawa et al., 2018).

Peat fires also affect soil temperature, structure, and ability to absorb water. Damage to the structure and reduced pore will cause increased soil fill weight - fires' open' the soil due to loss of litter, understorey, and canopy. The open ground will increase temperature, evaporation rate, loss of organic matter and decreased water content available (Lubis, 2016). In areas with low topography, peatland fires can change the volume, height, and water storage in wetlands after fires (Watts \& Kobziar, 2013).

Based on background, the purposes of this research are (1) to analyse the physical characteristics of soil (colour and soil texture) caused by fires in Banjarbaru, Indonesia (2) to investigate the chemical characteristics of soil ( $\mathrm{pH}$, dissolved $\mathrm{Fe}^{2+}, \mathrm{P}_{2} \mathrm{O}_{5}$, and $\mathrm{K}_{2} \mathrm{O}$ ) caused by fires.

\section{Materials and Methods}

This research was conducted in Banjarbaru, South Kalimantan Province, Indonesia. The city of Banjarbaru is geographically located between $3^{\circ} 25^{\prime} 40$ " $-3^{\circ} 28^{\prime} 37^{\prime \prime} \mathrm{LS}$ and $114^{\circ} 41^{\prime} 22^{\prime \prime}-114^{\circ} 54^{\prime} 25^{\prime \prime}$ BT (BPS, 2018). Soil samples were measured based on the location of peatland fires in Banjarbaru, obtained from the data of Sipongi hotspot points (SiPongi, 2018). There were 24 samples in total: 12 samples in October 2018 and 12 samples in January 2019 taken in the same location; they were taken based on fire occurrence on peatland in Banjarbaru, Indonesia. The sampling map is shown in Figure 1. The fires occurred around September 2018 in the research area. The samples were taken in October 2018, which was about one month after the fire; and in January 2019, which was about 4 months after the fire. One month after the fire, the land was still dry because the burning vegetation had not grown back. In January 2019, the land was wet and inundated because it was the rainy season, and the vegetation began to grow again. The land cover at the research location was shrubs. The location of research in the field can be seen in Figure 1 and Figure 2.

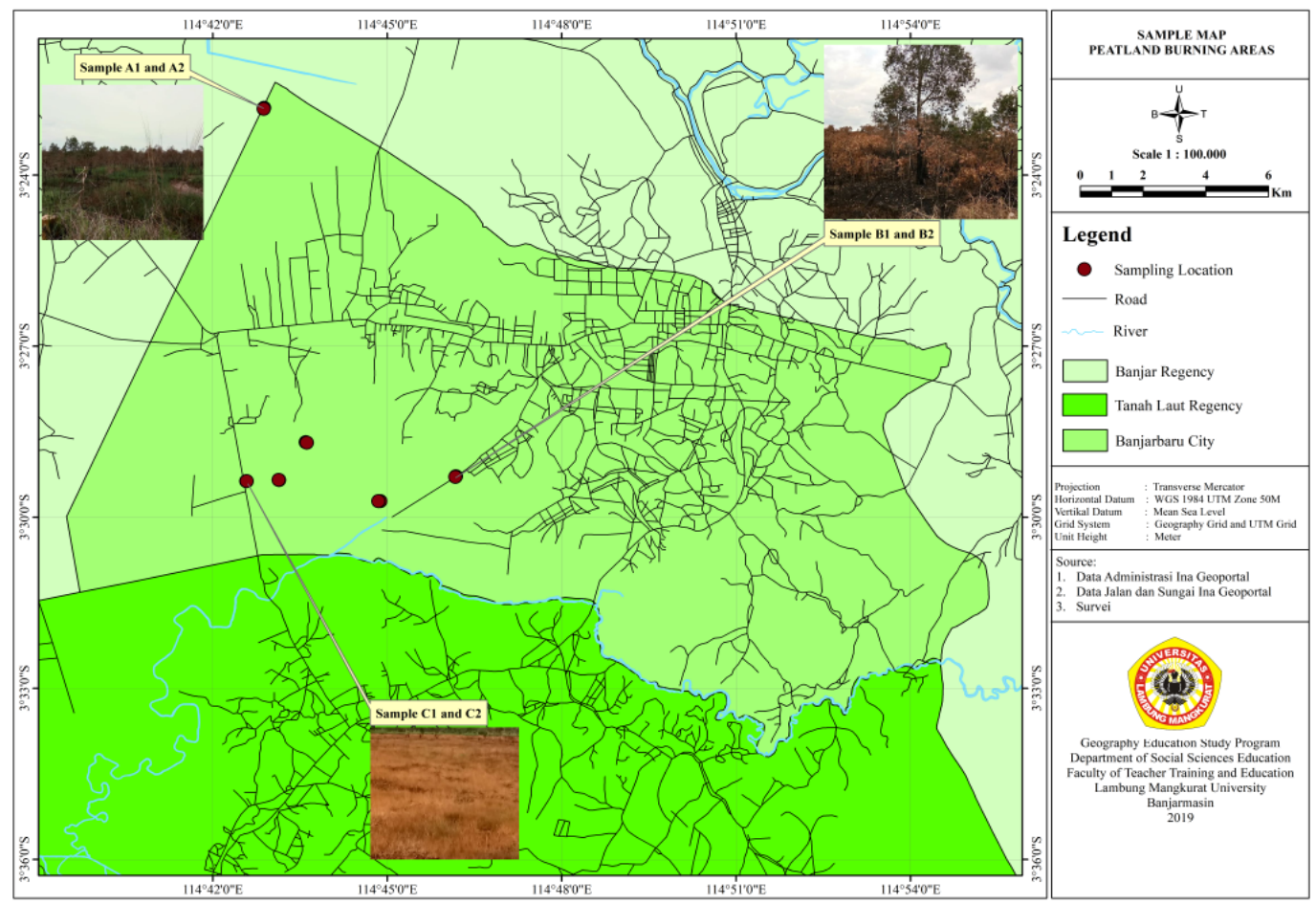

Fig. 1. Research location 
The sampling utilised a peat soil drill. The drilling depth was 1 meter. The fire has an impact on peat depth. The peat in the research area included shallow/thin peat types with an average thickness of about 50-100 $\mathrm{cm}$ and medium peat with a diameter of 100-200 $\mathrm{cm}$ based on the map of peat in Kalimantan (Wahyunto \& Suparto, 2004). In location, peat only has the depth about $10 \mathrm{~cm}-15 \mathrm{~cm}$ because of peat degradation due to fire. The extent of peat burned has a relationship with the fire recurrence (Wijedasa, 2016).

The samples were analysed regarding colour, $\mathrm{pH}$, texture, dissolved $\mathrm{Fe}^{2+}, \mathrm{P}_{2} \mathrm{O}_{5}$, and $\mathrm{K}_{2} \mathrm{O}$. Soil colour and $\mathrm{pH}$ were identified directly in the field. The soil colour was identified using Munsell's soil book; the soil pH was determined using Soil $\mathrm{pH}$ meter. The dissolved $\mathrm{Fe}^{2+}, \mathrm{P}_{2} \mathrm{O}_{5}$, and $\mathrm{K}_{2} \mathrm{O}$ were identified through laboratory tests.
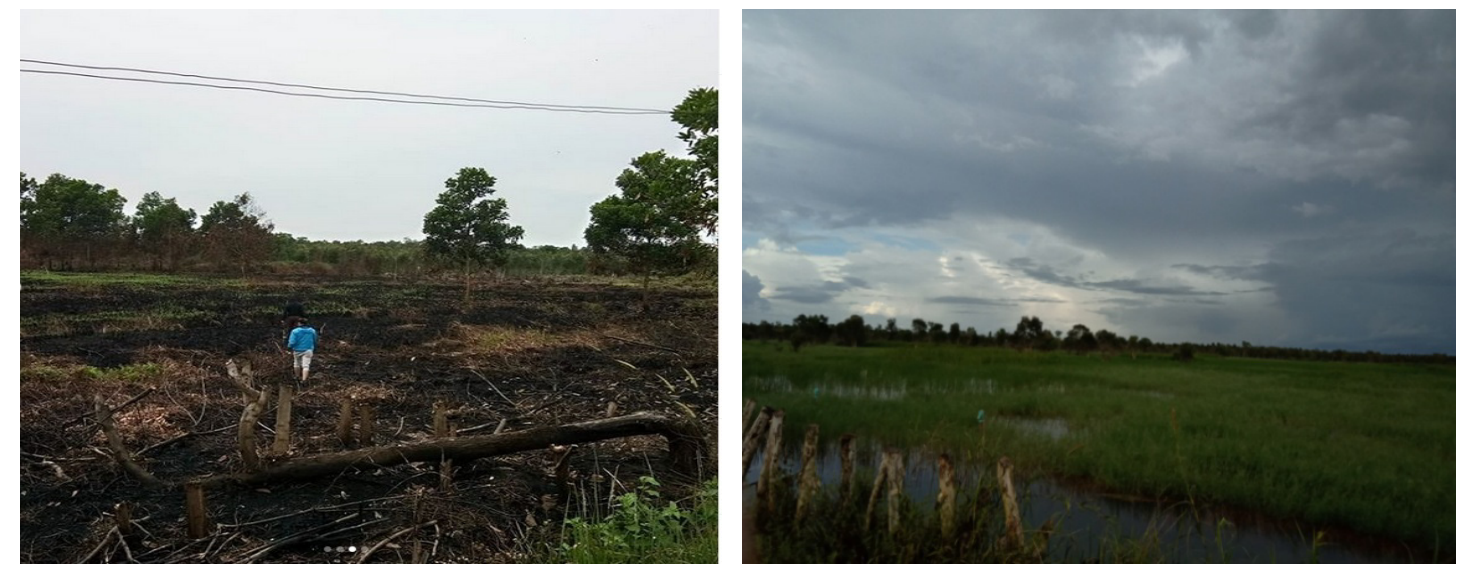

Fig. 2. Research location (a) One month after the fire (October 2018); and (b) Four months after the fire (January 2019)

\section{Results}

\section{Physical Characteristics of Soil in Burned Peatland}

\section{Soil Color} Table 1.

The colour characteristics of the soil at one month after the fire and 4 months after the fire are presented in

Tab. 1. The colour of soil on burned land

\begin{tabular}{ccccccc}
\hline $\begin{array}{c}\text { Samples } \\
\text { No. }\end{array}$ & X & & Y & \multicolumn{2}{c}{$\begin{array}{c}\text { Soil colour } \\
\text { 1 month after the fire }\end{array}$} \\
\hline A1 & 244795.8 & 9627240 & 7.5 YR 3/1 & Very Dark Grey & 7.5 YR3/2 & Dark Brown \\
A2 & 244786.0 & 9627210 & 7.5 YR 3/2 & Dark Brown & 7.5 YR3/2 \\
B1 & 245542.4 & 9613998 & 7.5 YR 3/2 & Dark Brown & 7.5 YR3/2 & Dark Brown \\
B2 & 245551.7 & 9613996 & 7.5 YR3/2 & Dark Brown & 7.5 YR3/2 & Dark Brown \\
C1 & 246582.6 & 9614035 & 7.5 YR3/2 & Dark Brown & 7.5 YR 3/2 Dark Brown \\
C2 & 246573.0 & 9614040 & 7.5 YR3/2 & Dark Brown & 7.5 YR3/2 & Dark Brown \\
D1 & 247435.5 & 9615259 & 7.5 YR3/2 & Dark Brown & 7.5 YR3/2 & Dark Brown \\
D2 & 247466.1 & 9615244 & 7.5 YR3/1 & Very Dark Grey & 7.5 YR3/2 & Dark Brown \\
E1 & 252218.8 & 9614169 & 7.5 YR3/2 & Dark Brown & 7.5 YR3/2 & Dark Brown \\
E2 & 252203.1 & 9614150 & 7.5 YR3/2 & Dark Brown & 7.5 YR3/2 & Dark Brown \\
F1 & 249811.4 & 9613362 & 7.5 YR3/1 & Very Dark Grey & 7.5 YR3/2 & Dark Brown \\
F2 & 249750.6 & 9613357 & 7.5 YR3/1 & Very Dark Grey & 7.5 YR3/2 & Dark Brown \\
\hline
\end{tabular}

The fire caused the colour to be very dark grey in within one month after the land burning. Moreover, fire locations at points A1, D2, F1, and F2 had very dark grey soil colours; the mixture of combustion ash resulted in the grey colour of the soil within a month after the fire.

Nonetheless, change in colour did not occur on all soils at the research site. Some research locations, such as points A2, B1, B2, C1, C2, D1, E1, and E2, did not experience changes in soil colour between 1-month postfire and 4-months post-fire. There was additional rainwater inundating the land in 4 months after the fire at the locations A1, D2, F1, and F2 washing residual combustion ash on the ground, which caused the soil to become dark brown. 


\section{Soil texture}

2.

The soil texture characteristics at one month after the fire and 4 months after the fire can be seen in Table

\begin{tabular}{|c|c|c|c|c|c|c|c|c|c|c|}
\hline \multirow{2}{*}{$\begin{array}{l}\text { Samples } \\
\text { No. }\end{array}$} & \multirow{2}{*}{$X$} & \multirow{2}{*}{ Y } & \multicolumn{4}{|c|}{$\begin{array}{c}\text { Soil Texture } \\
1 \text { month after the burning }\end{array}$} & \multicolumn{4}{|c|}{$\begin{array}{c}\text { Soil Texture } \\
4 \text { months after the burning }\end{array}$} \\
\hline & & & $\begin{array}{c}\text { Sand } \\
(\%)\end{array}$ & $\begin{array}{l}\text { Silt } \\
(\%)\end{array}$ & $\begin{array}{l}\text { Clay } \\
(\%)\end{array}$ & Texture & $\begin{array}{c}\text { Sand } \\
(\%)\end{array}$ & $\begin{array}{l}\text { Silt } \\
(\%)\end{array}$ & $\begin{array}{l}\text { Clay } \\
(\%)\end{array}$ & Texture \\
\hline A1 & 244795.8 & 9627240 & 1.3 & 49.05 & 49.65 & Silty Clay & 1.74 & 52.62 & 45.64 & Silty Clay \\
\hline A2 & 244786.0 & 9627210 & 5.53 & 49.68 & 44.79 & Silty Clay & 1.27 & 13.71 & 85.02 & Clay \\
\hline B1 & 245542.4 & 9613998 & 0.40 & 62.94 & 36.62 & $\begin{array}{l}\text { Silty Clay } \\
\text { Loam }\end{array}$ & 0.92 & 51.25 & 47.83 & Silty Clay \\
\hline B2 & 245551.7 & 9613996 & 0.23 & 63.68 & 36.10 & $\begin{array}{l}\text { Silty Clay } \\
\text { Loam }\end{array}$ & 2.17 & 59.03 & 38.80 & Silty Clay \\
\hline $\mathrm{C} 1$ & 246582.6 & 9614035 & 0.15 & 55.11 & 44.74 & Silty Clay & 1.05 & 56.21 & 42.74 & Silty Clay \\
\hline $\mathrm{C} 2$ & 246573.0 & 9614040 & 3.03 & 53.86 & 43.11 & Silty Clay & 0.95 & 55.20 & 43.85 & Silty Clay \\
\hline D1 & 247435.5 & 9615259 & 0.01 & 57.32 & 42.67 & Silty Clay & 25.97 & 39.39 & 34.64 & $\begin{array}{l}\text { Clay } \\
\text { Loam }\end{array}$ \\
\hline D2 & 247466.1 & 9615244 & 10.78 & 54.88 & 34.34 & $\begin{array}{l}\text { Silty Clay } \\
\text { Loam }\end{array}$ & 27.77 & 41.03 & 31.19 & $\begin{array}{l}\text { Clay } \\
\text { Loam }\end{array}$ \\
\hline E1 & 252218.8 & 9614169 & 30.47 & 37.30 & 32.23 & $\begin{array}{l}\text { Clay } \\
\text { Loam }\end{array}$ & 19.57 & 33.63 & 46.80 & Clay \\
\hline E2 & 252203.1 & 9614150 & 36.49 & 36.07 & 27.44 & $\begin{array}{l}\text { Clay } \\
\text { Loam }\end{array}$ & 21.34 & 29.25 & 49.42 & Clay \\
\hline F1 & 249811.4 & 9613362 & 7.01 & 57.36 & 35.63 & $\begin{array}{l}\text { Silty Clay } \\
\text { Loam }\end{array}$ & 2.80 & 56.85 & 40.35 & Silty Clay \\
\hline F2 & 249750.6 & 9613357 & 2.98 & 59.03 & 37.98 & $\begin{array}{l}\text { Silty Clay } \\
\text { Loam }\end{array}$ & 3.64 & 56.69 & 39.67 & Silty Clay \\
\hline
\end{tabular}

The soil texture was dominated by excellent size material such as silt and clay. At one month after the fire, the silt content dominated the surface compared to sand and clay. Minimum of sand content at 1 month was 0.01 , while the maximum of sand content at 1 month was 36.49. Besides, minimum of silt content at 1 month was 36.07 , while the maximum of silt content at 1 month was 63.68 . Further, the minimum of clay content at 1 month was 27.44, while the maximum of clay content at 1 month was 49.65 . Range of sand at 1 month was 36.48. Range of silt was 27.61. Range of clay was 22.21. In the other hand, the mean of sand was 9.1733 with the standard deviation were 12.18556 and variance was 148.488. Mean of silt was 53.0233, with the standard deviation were 8.81815 and variance was 77.760 and mean of clay was 38.7750 with the standard deviation were 6.30513 and variance was 39.755 .

The material content at 4 months was dominated by clay. Minimum of sand at 4 months was 0.92 , while the maximum of sand was 27.77. Minimum of silt was 13.71, while the maximum of silt was 59.03. Minimum of clay was 31.19, while the maximum of clay was 85.02. Range of sand, silt and clay contents were 26.85, 45.32, and 53.83. Means of sand, silt and clay contents were 9.0992, 45.4050, and 45.4958. Standard deviations of sand, silt and clay contents were 10.96999, 14.14991, and 13.56061. Variances of sand, silt and clay contents were 120.341, 200.220, and 183.890. Descriptive statistics of sand, silt and clay contents were presented in Table 3 .

Tab. 3. Descriptive statistics of sand, silt, and clay contents

\begin{tabular}{|c|c|c|c|c|c|c|c|c|}
\hline & \multirow{2}{*}{$\begin{array}{c}\mathrm{N} \\
\text { Statistic }\end{array}$} & \multirow{2}{*}{$\begin{array}{l}\text { Range } \\
\text { Statistic }\end{array}$} & \multirow{2}{*}{$\begin{array}{c}\text { Minimum } \\
\text { Statistic }\end{array}$} & \multirow{2}{*}{$\begin{array}{c}\text { Maximum } \\
\text { Statistic }\end{array}$} & \multicolumn{2}{|c|}{ Mean } & \multirow{2}{*}{$\begin{array}{c}\text { Std. Deviation } \\
\text { Statistic }\end{array}$} & \multirow{2}{*}{$\begin{array}{l}\text { Variance } \\
\text { Statistic }\end{array}$} \\
\hline & & & & & Statistic & Std. Error & & \\
\hline 1month_Sand & 12 & 36.48 & .01 & 36.49 & 9.1733 & 3.51767 & 12.18556 & 148.488 \\
\hline 1 month_Silt & 12 & 27.61 & 36.07 & 63.68 & 53.0233 & 2.54558 & 8.81815 & 77.760 \\
\hline 1 month_Clay & 12 & 22.21 & 27.44 & 49.65 & 38.7750 & 1.82013 & 6.30513 & 39.755 \\
\hline 4 months Sand & 12 & 26.85 & .92 & 27.77 & 9.0992 & 3.16676 & 10.96999 & 120.341 \\
\hline 4 months Silt & 12 & 45.32 & 13.71 & 59.03 & 45.4050 & 4.08473 & 14.14991 & 200.220 \\
\hline 4 months Clay & 12 & 53.83 & 31.19 & 85.02 & 45.4958 & 3.91461 & 13.56061 & 183.890 \\
\hline Valid N (listwise) & 12 & & & & & & & \\
\hline
\end{tabular}

The silt content was also higher in one month after the fire, compared to 4 months after. The clay content was also higher in 4 months than one month. The soil texture in one month after the fire was dominated by silty 
clay and silty clay loam, while the soil texture in 4 months after the fire was silty clay and clay loam. The fire created new ash on the ground so that the silt content in one month after the fire was higher than 4 months after. The rainwater in 4 months after the fire washed the residual combustion ash on the ground causing the soil texture to be dominated by silty clay.

\section{Chemical Characteristics of Soil in Peatland}

pH

The $\mathrm{pH}$ at one month after the fire and 4 months after the fire are displayed in Table 4.

\begin{tabular}{ccccc}
\multicolumn{5}{c}{ Tab. 4. The characteristics of $\mathrm{pH}$ on burned land } \\
\hline $\begin{array}{c}\text { Samples } \\
\text { No. }\end{array}$ & $\mathrm{X}$ & $\mathrm{pH}$ & $\begin{array}{c}\mathrm{pH} \\
\text { 1 month after the fire }\end{array}$ & $\begin{array}{c}\text { 4 months after the fire } \\
\text { A1 }\end{array}$ \\
A2 & 244795.8 & 9627240 & 6 & 4 \\
B1 & 244786.0 & 9627210 & 4 & 4 \\
B2 & 245542.4 & 9613998 & 4 & 4 \\
C1 & 245551.7 & 9613996 & 5 & 4 \\
C2 & 246582.6 & 9614035 & 5 & 4 \\
D1 & 246573.0 & 9614040 & 5 & 4 \\
D2 & 247435.5 & 9615259 & 5 & 4 \\
E1 & 247466.1 & 9615244 & 3 & 4 \\
E2 & 252218.8 & 9614169 & 5 & 4 \\
F1 & 252203.1 & 9614150 & 4 & 4 \\
F2 & 249811.4 & 9613362 & 6 & 4 \\
\hline
\end{tabular}

The soil $\mathrm{pH}$ a month after the fire ranged from 3-6, while the soil $\mathrm{pH} 4$ months after the fire was 4 . Mean of $\mathrm{pH}$ a month after the fire is $\mathrm{pH} 4$ month is 4 . The standard deviation of 1 month is 0.866 , while the standard deviation of 4 months is 0 . The average $\mathrm{pH}$ condition decreased. The peatland was dry in one month after the fire and was flooded after 4 months due to additional water from the rain and from canals around the peatland. Descriptive statistic of $\mathrm{pH}$ is presented in Table 5.

\begin{tabular}{|c|c|c|c|c|c|c|c|c|}
\hline & \multirow{2}{*}{$\begin{array}{c}\mathrm{N} \\
\text { Statistic }\end{array}$} & \multirow{2}{*}{$\begin{array}{l}\text { Range } \\
\text { Statistic }\end{array}$} & \multirow{2}{*}{$\begin{array}{l}\text { Minimum } \\
\text { Statistic }\end{array}$} & \multirow{2}{*}{$\begin{array}{c}\text { Maximum } \\
\text { Statistic }\end{array}$} & \multicolumn{2}{|c|}{ Mean } & \multirow{2}{*}{$\begin{array}{c}\text { Std. Deviation } \\
\text { Statistic }\end{array}$} & \multirow{2}{*}{$\begin{array}{l}\text { Variance } \\
\text { Statistic }\end{array}$} \\
\hline & & & & & Statistic & Std. Error & & \\
\hline 1 month & 12 & 3 & 3 & 6 & 4.75 & .250 & .866 & .750 \\
\hline 4 months & 12 & 0 & 4 & 4 & 4.00 & .000 & .000 & .000 \\
\hline $\begin{array}{c}\text { Valid N } \\
\text { (listwise) }\end{array}$ & 12 & & & & & & & \\
\hline
\end{tabular}

Fires added minerals from ash or charcoal to the soil, increasing the $\mathrm{pH}$ level of the soil within a month after the fire. Alkaline oxides from the ash remaining combustion added at the time of the fire increased the $\mathrm{pH}$ levels. The $\mathrm{pH}$ level decreased along with the inundation of peatlands during the rainy season. The dissolution of residual combustion ash in stagnant soil caused the $\mathrm{pH}$ levels to drop.

\section{Fe Dissolved $\left(\mathrm{Fe}^{2+}\right)$}

The characteristics of $\mathrm{Fe}^{2+}$ at one month after a fire and after 4 months of fire are presented in Table 6 .

The level of $\mathrm{Fe}^{2+}$ in one month of fire was lower than 4 months after, except at points A1, A2, E1, and E2. The highest $\mathrm{Fe}^{2+}$ at one month after the fire was $268.78 \mathrm{ppm}$, while the lowest was $18.18 \mathrm{ppm}$. Range of $\mathrm{Fe}^{2+}$ was 250.60 and the mean of $\mathrm{Fe}^{2+}$ at one month was 94.2592. Standard deviation at one month was 77.92506. 
Tab. 6. $\mathrm{Fe}^{2+}$ in burned land

\begin{tabular}{ccccc}
\hline $\begin{array}{c}\text { Samples } \\
\text { No. }\end{array}$ & $\mathrm{X}$ & $\mathrm{Y}$ & $\begin{array}{c}\mathrm{Fe}^{2+} 1 \text { month after the fire } \\
(\mathrm{ppm})\end{array}$ & $\begin{array}{c}\mathrm{Fe}^{2+} 4 \text { months after the fire } \\
(\mathrm{ppm})\end{array}$ \\
\hline A1 & 244795.8 & 9627240 & 125.53 & 30.39 \\
A2 & 244786.0 & 9627210 & 268.78 & 105.36 \\
B1 & 245542.4 & 9613998 & 71.67 & 150.11 \\
B2 & 245551.7 & 9613996 & 77.87 & 2200.74 \\
C1 & 246582.6 & 9614035 & 57.30 & 265.45 \\
C2 & 246573.0 & 9614040 & 48.82 & 305.89 \\
D1 & 247435.5 & 9615259 & 18.18 & 332.53 \\
D2 & 247466.1 & 9615244 & 76.89 & 344.78 \\
E1 & 252218.8 & 9614169 & 88.68 & 30.39 \\
E2 & 252203.1 & 9614150 & 227.75 & 105.36 \\
F1 & 249811.4 & 9613362 & 43.30 & 150.11 \\
F2 & 249750.6 & 9613357 & 26.34 & 2200.74 \\
\hline
\end{tabular}

Furthermore, the highest $\mathrm{Fe}^{2+}$ at 4 months after the fire was 2200.74 ppm, while the lowest was 30.39 ppm. The Fe monthly concentration was lost due to the combustion process. After 4 months of the fire, rainwater inundated the peatland and caused a reduction condition increasing $\mathrm{Fe}^{2+}$. Range of $\mathrm{Fe}^{2+}$ was 2170.35 , and the mean of $\mathrm{Fe}^{2+}$ at 4 months was 518.4875, with the standard deviation at 4 months of 793.33348 . Descriptive statistics of $\mathrm{Fe}^{2+}$ was presented in Table 7 .

\begin{tabular}{ccccccccc}
\hline & $\mathrm{N}$ & Range & Minimum & Maximum & & Mean & \multicolumn{3}{c}{ Std. Deviation } & \multicolumn{2}{c}{ Variance } \\
& Statistic & Statistic & Statistic & Statistic & Statistic & Std. Error & Statistic & Statistic \\
\hline 1 month & 12 & 250.60 & 18.18 & 268.78 & 94.2592 & 22.49503 & 77.92506 & 6072.315 \\
4 months & 12 & 2170.35 & 30.39 & 2200.74 & 518.4875 & 229.01565 & 793.33348 & 629378.007 \\
$\begin{array}{c}\text { Valid N } \\
\text { (listwise) }\end{array}$ & 12 & & & & & & & \\
\hline
\end{tabular}

\section{$\mathrm{P}_{2} \mathrm{O}_{5}$ Content} Table 8.

The characteristics of $\mathrm{P}_{2} \mathrm{O}_{5}$ levels at one month after the fire and after 4 months of fire can be seen in

\begin{tabular}{ccccc}
\multicolumn{5}{c}{ Tab. 8. $\mathrm{P}_{2} \mathrm{O}_{5}$ levels in burned land } \\
\hline $\begin{array}{c}\text { Samples } \\
\text { No. }\end{array}$ & $\mathrm{X}$ & $\mathrm{Y}$ & $\begin{array}{c}\mathrm{P}_{2} \mathrm{O}_{5} \\
\text { month after the fire } \\
(\mathrm{mg} / 100 \mathrm{~g})\end{array}$ & $\begin{array}{c}\mathrm{P}_{2} \mathrm{O}_{5} \\
\begin{array}{c}\text { months after the fire } \\
(\mathrm{mg} / 100 \mathrm{~g})\end{array}\end{array}$ \\
\hline A1 & 244795.8 & 9627240 & 14.50 & 2.89 \\
A2 & 244786.0 & 9627210 & 10.56 & 1.70 \\
B1 & 245542.4 & 9613998 & 14.61 & 2.03 \\
B2 & 245551.7 & 9613996 & 4.88 & 2.31 \\
C1 & 246582.6 & 9614035 & 4.45 & 2.40 \\
C2 & 246573.0 & 9614040 & 56.94 & 2.88 \\
D1 & 247435.5 & 9615259 & 2.99 & 3.19 \\
D2 & 247466.1 & 9615244 & 15.38 & 1.71 \\
E1 & 252218.8 & 9614169 & 26.11 & 3.27 \\
E2 & 252203.1 & 9614150 & 12.70 & 2.47 \\
F1 & 249811.4 & 9613362 & 10.79 & 7.33 \\
F2 & 249750.6 & 9613357 & 9.92 & 1.99 \\
\hline
\end{tabular}

$\mathrm{P}_{2} \mathrm{O}_{5}$ concentrations were higher one month after the fire and then decreased at 4 months after the fire. The highest $\mathrm{P}_{2} \mathrm{O}_{5}$ level at one month after the fire was $56.94 \mathrm{mg} / 100 \mathrm{~g}$, while the lowest was $2.99 \mathrm{mg} / 100 \mathrm{~g}$. The highest $\mathrm{P}_{2} \mathrm{O}_{5}$ level at 4 months after the fire was $7.33 \mathrm{mg} / 100 \mathrm{~g}$; while the lowest was $1.70 \mathrm{mg} / 100 \mathrm{~g}$. Range of $\mathrm{P}_{2} \mathrm{O}_{5}$ at 1 month was 53.95, while the range of $\mathrm{P}_{2} \mathrm{O}_{5}$ at 4 months was 5.63. Mean of $\mathrm{P}_{2} \mathrm{O}_{5}$ at 1 month was 15.3192, 
while the mean of $\mathrm{P}_{2} \mathrm{O}_{5}$ at 4 months was 2.8475 . Standard deviation at 1 month was 14.48576 , while standard deviation at 4 months was 1.50868 . Variance value at 1 month was 209.837 , while variance at 4 months was 2.276. Descriptive statistics of $\mathrm{P}_{2} \mathrm{O}_{5}$ was presented in Table 9.

Tab. 9. Descriptive statistics of $\mathrm{P}_{2} \mathrm{O}_{5}$ levels

\begin{tabular}{ccccccccc}
\hline & N & Range & Minimum & Maximum & \multicolumn{2}{c}{ Mean } & \multicolumn{2}{c}{ Std. Deviation } \\
& Statistic & Statistic & Statistic & Statistic & Statistic & Std. Error & Statistic & Statistic \\
\hline 1 month & 12 & 53.95 & 2.99 & 56.94 & 15.3192 & 4.18168 & 14.48576 & 209.837 \\
4 months & 12 & 5.63 & 1.70 & 7.33 & 2.8475 & .43552 & 1.50868 & 2.276 \\
$\begin{array}{c}\text { Valid N } \\
\text { (listwise) }\end{array}$ & 12 & & & & & & \\
\hline
\end{tabular}

$\mathrm{P}_{2} \mathrm{O}_{5}$ levels increased at one month after the fire due to the burning of organic matter and mineralisation caused by high temperatures. At 4 months after the fire, $\mathrm{P}_{2} \mathrm{O}_{5}$ levels decreased; this was resulted from the rainwater on peatland, causing loss of $\mathrm{P}_{2} \mathrm{O}_{5}$ levels in the soil since it dissolved in water inundating the peatlands.

\section{$\mathrm{K}_{2} \mathrm{O}$ Content} 10.

Characteristics of $\mathrm{K}_{2} \mathrm{O}$ levels at one month after the fire and 4 months after the fire are displayed in Table

Tab. 10. $\mathrm{K}_{2} \mathrm{O}$ levels in burned land

\begin{tabular}{ccccc}
\hline $\begin{array}{c}\text { Samples } \\
\text { No. }\end{array}$ & $\mathrm{X}$ & $\mathrm{Y}$ & $\begin{array}{c}\mathrm{K}_{2} \mathrm{O} \\
\text { month after the fire } \\
(\mathrm{mg} / 100 \mathrm{~g})\end{array}$ & $\begin{array}{c}\mathrm{K}_{2} \mathrm{O} \\
\text { months after the fire } \\
(\mathrm{mg} / 100 \mathrm{~g})\end{array}$ \\
\hline A1 & 244795.8 & 9627240 & 9.37 & 8.40 \\
A2 & 244786.0 & 9627210 & 8.95 & 4.81 \\
B1 & 245542,4 & 9613998 & 8.01 & 6.97 \\
B2 & 245551.7 & 9613996 & 7.66 & 6.87 \\
C1 & 246582.6 & 9614035 & 8.46 & 10.67 \\
C2 & 246573.0 & 9614040 & 8.05 & 9.67 \\
D1 & 247435.5 & 9615259 & 7.25 & 5.96 \\
D2 & 247466.1 & 9615244 & 7.82 & 5.28 \\
E1 & 252218.8 & 9614169 & 7.85 & 6.52 \\
E2 & 252203.1 & 9614150 & 7.87 & 3.18 \\
F1 & 249811.4 & 9613362 & 7.51 & 3.29 \\
F2 & 249750.6 & 9613357 & 7.68 & 2.56 \\
\hline
\end{tabular}

$\mathrm{K}_{2} \mathrm{O}$ levels were almost the same as $\mathrm{P}_{2} \mathrm{O}_{5}$ levels. One month after the fire, $\mathrm{K}_{2} \mathrm{O}$ levels were higher than 4 months after. The highest $\mathrm{K}_{2} \mathrm{O}$ level one month after the fire was $9.37 \mathrm{mg} / 100 \mathrm{~g}$, while the lowest was 7.25 $\mathrm{mg} / 100 \mathrm{~g}$. The highest $\mathrm{K}_{2} \mathrm{O}$ level at 4 months after the fire was $10.67 \mathrm{mg} / 100 \mathrm{~g}$, and the lowest was $2.56 \mathrm{mg} / 100$ g. Range of $\mathrm{K}_{2} \mathrm{O}$ level at 1 month was 2.12 , and the range of $\mathrm{K}_{2} \mathrm{O}$ level at 4 months was 8.11 . Mean of $\mathrm{K}_{2} \mathrm{O}$ level at 1 month was 8.0400, while the mean of $\mathrm{K}_{2} \mathrm{O}$ level at 4 months was 6.1817 . The standard deviation at 1 month was 0.60804 , while standard deviation at 4 months was 2.55265 . Variance at 1 month was 0.370 . Variance at 4 months was 6.516. $\mathrm{K}_{2} \mathrm{O}$ levels were higher at one month after a fire due to the burning of organic matter and mineralisation caused by high temperatures. At 4 months after the fire, $\mathrm{K}_{2} \mathrm{O}$ levels decreased at almost all samples except at $\mathrm{C} 1$ and $\mathrm{C} 2$. The cause of decreased $\mathrm{K}_{2} \mathrm{O}$ was rainwater inundating peatlands. The flooded peatlands washed $\mathrm{K}$ elements in the soil and dissolved them in water. Descriptive statistics of $\mathrm{K}_{2} \mathrm{O}$ levels were presented in Table 11.

Tab. 11. Descriptive statistics of $\mathrm{K}_{2} \mathrm{O}$ levels

\begin{tabular}{ccccccccc}
\hline & $\mathrm{N}$ & Range & Minimum & Maximum & \multicolumn{2}{c}{ Mean } & \multicolumn{2}{c}{ Std. Deviation } \\
& Statistic & Statistic & Statistic & Statistic & Statistic & Std. Error & Statistic & Statistic \\
\hline 1 month & 12 & 2.12 & 7.25 & 9.37 & 8.0400 & .17553 & .60804 & .370 \\
4 months & 12 & 8.11 & 2.56 & 10.67 & 6.1817 & .73689 & 2.55265 & 6.516 \\
$\begin{array}{c}\text { Valid N } \\
\text { (listwise) }\end{array}$ & 12 & & & & & & \\
\hline
\end{tabular}




\section{Discussion}

Fire causes an increase in $\mathrm{pH}, \mathrm{P}_{2} \mathrm{O}_{5}$, and $\mathrm{K}_{2} \mathrm{O}$ levels; it also brought changes in soil colour, texture, and decreased $\mathrm{Fe}^{2+}$. The residual combustion ash on the soil increased the silt, $\mathrm{pH}$, of $\mathrm{P}_{2} \mathrm{O}_{5}$, and $\mathrm{K}_{2} \mathrm{O}$ levels. Characteristic peat soil in October 2018 was soil colour was very dark grey-dark brown, the soil texture was silty clay and silty clay loam, the $\mathrm{pH}$ level was $3-6 . \mathrm{Fe}^{2+}$ was $18.18-268.78 \mathrm{ppm}$. Mean of $\mathrm{Fe}^{2+}$ was $94.2592 \mathrm{ppm}$. $\mathrm{P}_{2} \mathrm{O}_{5}$ content was $2.99-56.94 \mathrm{mg} / 100 \mathrm{~g}$. $\mathrm{P}_{2} \mathrm{O}_{5}$ mean was $15.3192 \mathrm{mg} / 100$ g. $\mathrm{K}_{2} \mathrm{O}$ content was $7.25-9.37 \mathrm{mg} / 100$ g. Mean of $\mathrm{K}_{2} \mathrm{O}$ content was $8.0400 \mathrm{mg} / 100 \mathrm{~g}$.

The $\mathrm{pH}, \mathrm{P}_{2} \mathrm{O}_{5}$, and $\mathrm{K}_{2} \mathrm{O}$ levels decreased along with rainwater on the peatland due to the loss of residual combustion ash on it. $\mathrm{Fe}^{2+}$ increased with the addition of rainwater on the peatland. The reduction reaction increased $\mathrm{Fe}^{2+}$. In January 2019, characteristics of peat soil were the soil colour was dark brown, the soil texture was silty clay and clay loam, and the $\mathrm{pH}$ level was 4 . The concentration of $\mathrm{Fe}^{2+}$ was $30.39-2200.74 \mathrm{ppm}^{2} \mathrm{Fe}^{2+}$ mean was 518.4875 ppm. $\mathrm{P}_{2} \mathrm{O}_{5}$ content was $1.70-7.33 \mathrm{mg} / 100 \mathrm{~g}$. Mean of $\mathrm{P}_{2} \mathrm{O}_{5}$ was $2.8475 \mathrm{mg} / 100 \mathrm{~g}$. $\mathrm{K}_{2} \mathrm{O}$ content was $2.56-10.67 \mathrm{mg} / 100 \mathrm{~g}$. Mean of $\mathrm{K}_{2} \mathrm{O}_{5}$ was $6.1817 \mathrm{mg} / 100 \mathrm{~g}$.

The soil in peatland is a land easily subjected to change and damage. Fires cause changes to the soil's nature. Changes in soil properties can be physical, chemical, and biological. Fires on organic soil can increase some nutrients, such as the P elements. Fires can increase $\mathrm{pH}$ levels, $\mathrm{P}$ levels, and $\mathrm{K}$ levels. The fire effects were limited to Fe and related to $\mathrm{pH}$ and organic content (Norouzi \& Ramezanpour, 2013). Characteristic of soils was found that $\mathrm{pH}$ levels, soil fertility, and $\mathrm{P}$ were dissolved (Tata et al., 2018). The land fire was an increase in $\mathrm{pH}, \mathrm{P}$ and $\mathrm{K}$ levels in the soil (Ekinci, 2006; Wasis et al., 2019). Ca also experienced a significant increase after land fires (Wasis et al., 2019). P levels increased 6 times in burned soils compared to unburned soils, especially at the surface of the soil (Sulwiński et al., 2017). Organic phosphorus (Po) decreases, but inorganic phosphorus (Pi) increases after the land fire (Wang et al., 2015).

Fires can indeed add $\mathrm{P}_{2} \mathrm{O}_{5}$ and $\mathrm{K}_{2} \mathrm{O}$ to the soil, but they are only temporary. $\mathrm{P}_{2} \mathrm{O}_{5}$ and $\mathrm{K}_{2} \mathrm{O}$ will be lost due to the rainwater inundated. The damage produced by combustion is more considerable. The accumulation of ashes in wooded area peat fires impacted place right away improved $\mathrm{pH}$, organic matter, humic acid content, hydrophobicity, available-N and available-K. However, their availabilities had solely been briefed as they were without difficulty diminished and washed way, which results in long-term degradation (Agus et al., 2019). Fires burning over these landscapes moreover expend surface peat, uncovering more seasoned peat strata (Sinclair et al., 2020). The impact of peat fires is not only on the ground but also affects up to 30-50 cm deep (Yustiawati et al., 2016). The fire also causes a decrease in peat soil thickness of 10-15 cm (Wasis et al., 2019). In the research location, we found the peat depth only about $10-15 \mathrm{~cm}$ due to land fire every year. This condition is characteristic of land degradation.

The land fire also has damaged peatland organism. Peatland fires cause $100 \%$ mortality of flora and fauna of the soil. Total microorganisms, total fungi, and soil respiration have decreased due to land fires (Wasis et al., 2019). Species are showed more significant damage at higher temperatures, with harm taking place at once after heat exposure (Noble et al., 2019). Wetland fires influence aquatic animal and plant neighbourhood structure, at least for brief intervals post-fire (Venne et al., 2016). In research, we found that warm temperature after the fire and no organism in soil, and this is the loses of land fire.

\section{Conclusions}

Fires occurred in peat soil in Banjarbaru, South Kalimantan, Indonesia brought changes to the soil physical and chemical properties, but the effect of fire is only temporary. This research recommends no land burning to prepare agriculture land, although the land burning increases $\mathrm{pH}, \mathrm{P}_{2} \mathrm{O}_{5}$ and $\mathrm{K}_{2} \mathrm{O}$, due to the land fire has the highest effect on land degradation. The next research should be expanded to the other peatland in Indonesia and more of soil properties to understand the more impact of fire for peatland properties.

\section{References}

Agus, C., Azmi, F. F., Ilfana, Z. R., Wulandari, D., Rachmanadi, D., Harun, M. K., \& Yuwati, T. W. (2019). The Impact of Forest Fire on the Biodiversity and the Soil Characteristics of Tropical Peatland: Springer. https//doi.org/10.1007/978-3-319-98681-4_18

Agus, C., Ilfana, Z., Azmi, F., Rachmanadi, D., Wulandari, D., Santosa, P., Harun, M., Yuwati, T., \& Lestari, T. (2020). The effect of tropical peat land-use changes on plant diversity and soil properties. International Journal of Environmental Science and Technology, 17(3). https://doi.org/10.1007/s13762-019-02579-x

Arisanty, D., Adyatma, S., Muhaimin, M., \& Nursaputra, A. (2019). Landsat 8 OLI TIRS Imagery Ability for Monitoring Post Forest Fire Changes. Pertanika Journal of Science \& Technology, 27(3). 
Blistanova, M., Zeleňáková, M., Blistan, P., \& Ferencz, V. (2016). Assessment of flood vulnerability in Bodva river basin, Slovakia. Acta Montanistica Slovaca, 21(1). https://10.3390/ams21010019

BPS. (2018). Regional Statistics of Banjarbaru City. Banjarbaru: BPS Retrieved from https://banjarbarukota.bps.go.id/. Access date: 5 October 2019

Brown, L. E., Palmer, S. M., Johnston, K., \& Holden, J. (2015). Vegetation management with fire modifies peatland soil thermal regime. Journal of Environmental Management, 154. https://doi.org/10.1016/j.jenvman.2015.02.037

Cahyono, S. A., Warsito, S. P., Andayani, W., \& Darwanto, D. H. (2015). Faktor-faktor yang mempengaruhi kebakaran hutan di indonesia dan implikasi kebijakannya (Factors Affecting Forest Fires in Indonesia and the Policy Implications). Jurnal Sylva Lestari, 3(1). https://dx.doi.org/10.23960/js113103-112

Ekinci, H. (2006). Effect of forest fire on some physical, chemical and biological properties of soil in Çanakkale, Turkey. International Journal of Agriculture and Biology, 8(1).

Frolking, S., Talbot, J., Jones, M. C., Treat, C. C., Kauffman, J. B., Tuittila, E.-S., \& Roulet, N. (2011). Peatlands in the Earth's 21st century climate system. Environmental Reviews, 19. https://doi.org/10.1139/a11-014

Hansson, A., \& Dargusch, P. (2017). An estimate of the financial cost of peatland restoration in Indonesia. Case Studies in the Environment, 2(1). https://doi.org/10.1525/cse.2017.000695

Jones, W. (2005). Peat Fires: the dangers from a Fire Manager's point of view. Journal of the Royal Society of Western Australia, 88.

Joosten, H. (2009). The Global Peatland CO2 Picture: Peatland Status and Drainage Related Emissions in All Countries of the World. Germany: Universität Greifswald, Wetlands International.

Joosten, H., Tapio-Biström, M.-L., \& Tol, S. (2012). Peatlands: guidance for climate change mitigation through conservation, rehabilitation and sustainable use. Germany: Food and Agriculture Organization of the United Nations

Könönen, M., Jauhiainen, J., Laiho, R., Kusin, K., \& Vasander, H. (2015). Physical and chemical properties of tropical peat under stabilised land uses. Mires and Peat, 16(8).

Kumparan. (2018). Peatland Areas Dominate 2,005 hectares of forest and land fires in South Kalimantan. Retrieved from kumparan.com/trubus-id/kawasan-lahan-gambut-dominasi-2-005-hektare-kathutla-dikalsel-1537065212533751796. Access date: 5 October 2019

Lubis, A. H. (2016). Responses of Peat Soil Characteristics on Fire. Institut Pertanian Bogor, Bogor.

Marlier, M. E., Liu, T., Yu, K., Buonocore, J. J., Koplitz, S. N., DeFries, R. S., ... \& Myers, S. S. (2019). Fires, smoke exposure, and public health: An integrative framework to maximise health benefits from peatland restoration. GeoHealth, 3(7). https://doi.org/10.1029/2019GH000191

Noble, A., Crowle, A., Glaves, D. J., Palmer, S. M., \& Holden, J. (2019). Fire temperatures and Sphagnum damage during prescribed burning on peatlands. Ecological Indicators, 103(-). https://10.1016/j.ecolind.2019.04.044

Norouzi, M., \& Ramezanpour, H. (2013). Effect of fire on soil nutrient availability in forests of Guilan, north of Iran. Carpathian Journal of Earth and Environmental Sciences, 8(1).

Novitasari, N., Sujono, J., Harto, S., Maas, A., \& Jayadi, R. (2019). Drought Index for Peatland Wildfire Management in Central Kalimantan, Indonesia During El Nino Phenomenon. Journal of Disaster Research, 14(7). https://10.20965/jdr.2019.p0939

Nugroho, Y. S. (2017). Integrating Wildland and Urban Fire Risks in Local Development Strategies in Indonesia. In Harada, Matsuyama, Himoto, Nakamura, \& Wakatsuki (Eds.), In Fire Science and Technology 2015. Singapore: Springer. https://doi.org/10.1007/978-981-10-0376-9 4

Page, S. (2016). Understanding the Dynamics of Peatland Fires in Indonesia. Pengelolaan Lanskap Berkelanjutan, 1(1), 4-13.

Prayoto, T., Ishihara, M., Firdaus, R., \& Nakagoshi, N. (2017). Peatland Fires in Riau, Indonesia, in Relation to Land Cover Type, Land Management, Landholder, and Spatial Management. Journal of Environmental Protection, 8(11). https://10.4236/jep.2017.811081

Rajiani, I., \& Pypłacz, P. (2018). National culture as modality in managing the carbon economy in Southeast Asia. Polish Journal of Management Studies, 18. https://10.17512/pjms.2018.18.1.22

Rauf, A. (2016). Dampak Kebakaran Hutan Tanaman Kelapa Sawit terhadap Lahan Gambut di Kabupaten Aceh Barat Daya terhadap Sifat Lahan Gambut (The Impact of Oil Palm Plantation Fires on Peatlands in Southwest Aceh District on the Characteristic of Peatlands). Jurnal Pertanian Tropik, 3(3). https://doi.org/10.32734/jpt.v3i3.2985

Saputra, E. (2019). Beyond fires and deforestation: Tackling land subsidence in peatland areas, a case study from Riau, Indonesia. Land, 8(5). https://10.3390/land8050076

Sazawa, K., Wakimoto, T., Fukushima, M., Yustiawati, Y., Syawal, M. S., Hata, N., Taguchi, S., Tanaka, S., Tanaka, D., \& Kuramitz, H. (2018). Impact of Peat Fire on the Soil and Export of Dissolved Organic 
Carbon in Tropical Peat Soil, Central Kalimantan, Indonesia. ACS Earth and Space Chemistry, 2(7). https://doi.org/10.1021/acsearthspacechem.8b00018

Sinclair, A. L., Graham, L. L., Putra, E. I., Saharjo, B. H., Applegate, G., Grover, S. P., \& Cochrane, M. A. (2020). Effects of distance from canal and degradation history on peat bulk density in a degraded tropical peatland. Science of The Total Environment, 699. https://doi.org/10.1016/j.scitotenv.2019.134199

SiPongi. (2018). Peatland fires in Banjarbaru. Retrieved 5 Oktober 2019 http://sipongi.menlhk.go.id/

Smith, S. M., Newman, S., Garrett, P. B., \& Leeds, J. A. (2001). Differential effects of surface and peat fire on soil constituents in a degraded wetland of the northern Florida Everglades. Journal of Environmental Quality, 30(6). https://10.2134/jeq2001.1998

Sulwiński, M., Mętrak, M., \& Suska-Malawska, M. (2017). Long-term fire effects of the drained open fen on organic soils. Archives of Environmental Protection, 43(1). https://10.1515/aep-2017-0002

Susandi, Oksana, \& Arminudin, A. T. (2015). Analisis sifat fisika tanah gambut pada hutan gambut di Kecamatan Tambang Kabupaten Kampar Provinsi Riau (Analysis of Physical Characteristics of Peatlands in Peat Forests in Tambang Sub-District, Kampar District, Riau Province). Jurnal Agroteknologi, 5(2). https://dx.doi.org/10.24014/ja.v5i2.1351

Tacconi, L. (2003). Fires in Indonesia: Causes, Costs and Policy Implications. Indonesia: Center for International Forestry Research (CIFOR). https://doi.org/10.17528/cifor/001200

Tata, H. L., Narendra, B. H., \& Mawazin. (2018). Forest and land fires in Pelalawan District, Riau, Indonesia: Drivers, pressures, impacts and responses. Biodiversitas Journal of Biological Diversity, 19(2). https://doi.org/10.13057/biodiv/d190224

Turetsky, M. R., Benscoter, B., Page, S., Rein, G., Van Der Werf, G. R., \& Watts, A. (2015). Global vulnerability of peatlands to fire and carbon loss. Nature Geoscience, 8(1). https://doi.org/10.1038/ngeo2325

Venne, L. S., Trexler, J. C., \& Frederick, P. C. (2016). Prescribed burn creates pulsed effects on a wetland aquatic community. Hydrobiologia, 771(1). https://10.1007/s10750-016-2640-y

Vetrita, Y., \& Cochrane, M. A. (2020). Fire Frequency and Related Land-Use and Land-Cover Changes in Indonesia's Peatlands. Remote Sensing, 12(1). https://doi.org/10.3390/rs12010005

Wahyunto, R. S., \& Suparto, S. H. (2004). Map of peatland distribution area and carbon content in Kalimantan. Bogor: Wetland International-Indonesia.

Wang, G., Yu, X., Bao, K., Xing, W., Gao, C., Lin, Q., \& Lu, X. (2015). Effect of fire on phosphorus forms in Sphagnum moss and peat soils of ombrotrophic bogs. Chemosphere, 119. https://doi.org/10.1016/j.chemosphere.2014.01.084

Wasis, B., Saharjo, B. H., \& Putra, E. I. (2019). Impacts of peat fire on soil flora and fauna, soil properties and environmental damage in Riau Province, Indonesia. Biodiversitas Journal of Biological Diversity, 20(6). https://Doi.Org/10.13057/Biodiv/D200639

Watts, A. C., \& Kobziar, L. N. (2013). Smoldering Combustion and Ground Fires: Ecological Effects and MultiScale Significance. Fire Ecology, 9(1). https://10.4996/fireecology.0901124

Wijedasa, L. S. (2016). Peat soil bulk density important for estimation of peatland fire emissions. Global change biology, 22(9). https://doi.org/10.1111/gcb.13364

Wiri, Astiani, D., \& Fernando, T. (2017). Peat Biomass Loss Due to Forest Fires. Jurnal Hutan Lestari, 3(2).

Xu, J., Morris, P. J., Liu, J., \& Holden, J. (2018). PEATMAP: Refining estimates of global peatland distribution based on a meta-analysis. Catena, 160. https://10.1016/j.catena.2017.09.010.

Yustiawati, Sazawa, K., Syawal, M. S., Kuramitz, H., Saito, T., Hosokawa, T., Kurasaki, M., \& Tanaka, S. (2016). Peat Fire Impact on Water Quality and Organic Matter in Peat Soil Tropical Peatland Ecosystems (pp. 281-296): Springer. https://doi.org/10.1007/978-4-431-55681-7_18

Zulkifli, I., \& Kamarubayana, L. (2017). Studi Pengendalian Kebakaran Hutan di Wilayah Kelurahan Merdeka Kecamatan Samboja Kalimantan Timur (Study on Forest Fire Control in the Merdeka Village, Samboja Sub-District, East Kalimantan). AGRIFOR, 16(1). ISSN: 2503-4960 